\section{No Tillage and Strip Tillage Effects on Plant Performance, Weed Suppression, and Profitability in Transitional Organic Broccoli Production}

\author{
Dana Jokela and Ajay Nair ${ }^{1}$ \\ Horticulture Hall, Department of Horticulture, Iowa State University, Ames, \\ IA 50011
}

Additional index words. cereal rye, cost of production, cover crops, roller-crimper, soil temperature, weed suppression

\begin{abstract}
Organic no-till and strip-till systems have gained attention because of their reported capacity to enhance soil health and suppress annual weeds. This study, conducted at the Horticulture Research Station, Ames, IA, over 2 years (2013-14 and 2014-15) compared a cover crop-based no tillage (NT), strip tillage (ST), and conventional tillage (CT) in transitional organic broccoli (Brassica oleracea L. var. italica) production, with data collected on broccoli yield and quality, plant health, weed suppression, soil temperature, and cost of production. A cover crop mixture of cereal rye (Secale cereale L.) and hairy vetch (Vicia villosa Roth.) was seeded in all plots in September, and was ended by rolling and crimping (NT and ST) or soil incorporation (CT) in late spring the following year. Each whole-plot tillage treatment was split into two subplot fertility treatments - one based entirely on organic preplant granular fertilizer, and the other split between preplant granular fertilizer and postplanting fertigation- to test the effect of fertigation on yield and plant growth under the typically nitrogen (N)-limited reduced tillage conditions. In 2014, yield of broccoli was highest in CT treatments, averaging $5.4 \mathrm{t} \cdot \mathrm{ha}^{-1}$, with no difference between ST and NT treatments. In 2015, yields were equal among tillage treatments, averaging $20.0 \mathrm{t} \cdot \mathrm{ha}^{-1}$. Changing the timing of fertilizer application through the use of fertigation did not affect yield. Weed density and biomass were lowest in the between-row (BR) regions of NT and ST plots in 2014, indicating effective early-season weed suppression. In 2015, NT and ST plots generally had lower weed biomass and density compared with CT plots, but weed growth in BR and in-row (IR) regions of NT and ST plots was similar. Soil temperature was highest in CT plots throughout the year, and higher in ST than in NT plots only during some periods. While production costs did vary slightly across treatments, profit per hectare was most strongly affected by yield. Our findings suggest that cover crop-based organic NT and ST systems may be viable options for organic broccoli growers.
\end{abstract}

Researchers have increasingly been investigating cover crop-based reduced tillage systems, such as NT and ST, as methods for mitigating some of the adverse effects of CT. In these systems, cover crops are grown before cash crop establishment and are ended without incorporating residue into the soil, thus leaving a surface mulch into which the subsequent cash crop can be planted. Although much of this research has been conducted on agronomic crops, such as corn and soybeans, more research is needed to investigate such systems in vegetable production. Application of cover crop-based reduced tillage in vegetable production systems face

\footnotetext{
Received for publication 22 Feb. 2016. Accepted for publication 21 July 2016.

We would like to thank and acknowledge the Ceres Trust and United States Department of Agriculture North Central Sustainable Agriculture Research and Education grant number GNC14-189 for the financial support to conduct this study.

${ }^{1}$ Corresponding author. E-mail: nairajay@iastate. edu.
}

challenges due to 1) necessity of producing large cover crop biomass, 2) managing cover crop residue to provide maximum weed suppression and reduced $\mathrm{N}$ immobilization, and 3) the ability of cover crop-based cropping systems to align with conservation tillage approaches.

Challenges also exist in effective cover crop termination strategies in organic vegetable production. Many cover crop-based conservation tillage studies relied on herbicide for cover crop termination and supplemental weed control (Abdul-Baki et al., 1996; Brainard and Noyes, 2012; Haramoto and Brainard, 2012; Peachey et al., 2004). Organic producers, however, typically end cover crops mechanically_using a tool such as a rollercrimper or flail mower - and have few options for chemical control of weeds that come up through the cover crop mulch. Weed management through rolled cover crops has long been an attractive proposition for organic producers. The thick mulch between rows can drastically reduce weed pressure, especially pressure from annual weeds, compared with bare ground, saving time on cultivating and weeding, and reducing the need for herbicides (Nair et al., 2015). Cover crop residues on the soil surface can affect light availability, temperature, and moisture levels, reducing the number of germinating weed species (Creamer et al., 1996b). This is true for the BR region of the crop, but weeds that grow in the IR region could be a challenge. Studies in cover crop-based ST systems suggest a need to develop weed management strategies that target distinct zones while balancing crop and soil management tradeoffs (Brainard et al., 2013).

To make NT and ST systems viable options for growers, it is crucial to identify yield-limiting factors and develop strategies to mitigate them. There has been considerable variability in vegetable crop yield under cover crop-based reduced tillage in prior organic research. Some studies found that NT treatments yielded as much or more than CT in production of tomatoes (Creamer et al., 1996a; Delate et al., 2012), bell pepper (Delate et al., 2008), spinach (Lounsbury and Weil, 2015), and onion (Vollmer et al., 2010), while others found that NT treatments yielded poorly (Díaz-Pérez et al., 2008; Leavitt et al., 2011). Schellenberg et al. (2009) found that an NT system using flail mowed warmseason legume cover crops [lablab (Dolichos lablab L.), soybean (Glycine max L.), sunn hemp (Crotalaria juncea L.), and a mixture of sunn hemp and cowpea (Vigna sinensis Endl.)] had similar yields for spring broccoli, but reduced yields for fall broccoli, compared with CT.

The ST production system with rolled and crimped cereal rye has been shown to promote soil health, resulting in significant increases in soil aggregate stability, potentially mineralizable $\mathrm{N}$, active soil carbon $(\mathrm{C})$, and microbial activity when compared with a conventionally tilled production system (Pieper et al., 2015). However, it was not effective for production of vegetables, with the ST plots having the lowest yields potentially due to failure of the cereal rye mulch to suppress weeds throughout the growing season and reduced decomposition and $\mathrm{N}$ mineralization due to cooler soils. Similar challenges exist in cover crop-based NT production systems. Nitrogen is often a limiting factor in rolled cover crop systems (Wells et al., 2013) and in organic systems (Berry et al., 2002), where plant-available $\mathrm{N}$ is typically derived from mineralization of particulate organic matter, legume-fixed $\mathrm{N}$, and supplemental purchased fertilizers (Gaskell and Smith, 2007). In a study using agronomic crop residue, Aulakh et al. (1991) showed that nonincorporated residue is mineralized more slowly than incorporated residue, and residue with a high $\mathrm{C}: \mathrm{N}$ ratio causes a greater rate of $\mathrm{N}$ immobilization. Cereal rye ( $S$. cereale), a cover crop commonly used in conjunction with reduced tillage, has a high $\mathrm{C}: \mathrm{N}$ ratio at the time of termination when mowed or rolled, increasing the likelihood of reduced $\mathrm{N}$ availability in these systems. An additional challenge in organic NT systems is the difficulty of sidedressing organic granular fertilizers with typical equipment, because fertilizer cannot be effectively 
incorporated into the soil without disturbing the cover crop mulch. Use of fertigation may be one strategy to provide inorganic $\mathrm{N}$ to the crop in otherwise $\mathrm{N}$-limited conditions.

Lower soil temperature, caused by the insulative effects and high albedo of surface residue (Baker et al., 2007), may also contribute to reduced yields in cover crop-based NT systems. Soil temperature has been shown to be lower in NT than in CT (Johnson and Lowery, 1985; Nyborg and Malhi, 1989), and in mulched as compared with bare ground systems (Creamer et al., 1996a; Mochizuki et al., 2008). The heavy residue left on the soil surface in cover crop-based NT systems is thus likely to reduce soil temperature.

In ST, untilled cover crop residue protects soil between rows, whereas tillage, which is confined to the planting row, minimizes the negative effects of tillage while promoting $\mathrm{N}$ mineralization and soil warming. As compared with NT, ST may produce higher IR soil temperature (Licht and Al-Kaisi, 2005) and may increase IR $\mathrm{N}$ availability because the cover crop in that region is incorporated rather than left on the soil surface. As compared with CT, ST conserves soil moisture (Licht and Al-Kaisi, 2005) and retains many of the soil health benefits of NT in the BR region. To our knowledge, no studies have compared NT, ST, and CT side by side in an organic vegetable production system. Additionally, there could be differences in economic returns between CT, ST, and NT systems due to differences in tillage costs, machinery and fuel costs, yield, and labor involved. Strip tillage system has been shown to reduce tillage costs and machinery operating time by an average of $\$ 36.50$ and 0.47 $\mathrm{h} \cdot \mathrm{ha}^{-1}$, respectively, as compared with CT (Luna and Staben, 2002).

Our objectives were to determine the effects of tillage system and split fertilizer application on crop yield, plant health, weed biomass, and economic returns, and in particular, to evaluate ST as a tool for increasing soil temperature and improving $\mathrm{N}$ availability to the crop compared with NT. Our hypothesis is that 1) the split application of fertilizer (preplant and successive applications of fish emulsion) would be most effective in supplying plant-available $\mathrm{N}$ than a one-time preplant application and 2) weed suppression property of rolled cover crop mulch will depend on the region (IR or BR), with higher degree of weed suppression in the BR than IR region.

\section{Materials and Methods}

Site description. The experiment was conducted at the Iowa State University Horticulture Research Station in Ames, IA, in 2013-14 and 2014-15. The soils at the 201314 site were moderately well-drained Clarion and somewhat poorly drained Nicollet loams (fine-loamy, mixed, superactive, mesic Typic Hapludolls). This land was first-year transitional organic and previous crops were oilseed radish (Raphanus sativus L.), yellow mustard (Sinapis alba L.), and cereal rye, followed by 3 months' bare fallow before seeding cover crops in Fall 2013. The soil at the 2014-15 transitional organic site was a well-drained Lester loam (fine-loamy, mixed, superactive, mesic Mollic Hapludalf), and the previous crop was organically managed alfalfa (Medicago sativa L.).

Experimental design. The experimental design was a split-plot randomized complete block design with four replications. The wholeplot treatments were CT, ST, or NT. The subplot fertility treatments were preplant fertilizer only, split fertilizer application, or a nofertilizer control. Whole-plot dimensions were $4.6 \mathrm{~m} \times 10.7 \mathrm{~m}$, and each subplot consisted of a single 10.7-m row. Each whole plot contained five rows, with outer rows treated as guard rows. Rows were spaced $0.8 \mathrm{~m}$ apart and plants were spaced $0.3 \mathrm{~m}$ apart within rows.

Field management and vegetable culture. Dates of field operations and major data collection events can be found in Table 1 . Before cover crop establishment, soil was tilled with a Terra Force GM102 rotary tiller (Terra Force, Inc., Carrollton, TX) and compressed by using a modified Brillion cultimulcher (Landoll Corporation, Marysville, KS) to provide a firm seedbed for cover crop establishment. All treatments were planted to a mixture of cereal rye 'Wheeler' and hairy vetch ( $V$. villosa Roth., variety not stated in 2013-14 and 'Purple Bounty' in 2014-15). The cover crop was established on 10 Sept. 2013 and 8 Sept. 2014 at $3.8 \mathrm{~cm}$ depth using a no-till grain drill (Tye Pasture Pleaser, AGCO, Duluth, GA) with $0.3 \mathrm{~m}$ row spacing. The cereal rye was seeded at a rate of $112.1 \mathrm{~kg} \cdot \mathrm{ha}^{-1}$ and hairy vetch was seeded at a rate of $28 \mathrm{~kg} \cdot \mathrm{ha}^{-1}$. Seeds of hairy vetch were inoculated with Rhizobium leguminosarum biovar viceae (INTX Microbials LLC, Kentland, IN).

Strips that were $0.3 \mathrm{~m}$ wide were tilled in ST plots on 14 Nov. 2013 and 12 Oct. 2014 using a Hiniker 6000 strip tiller (Hiniker Co., Mankato, MN). The fall ST operation was carried out at an earlier date in 2014 than in 2015 due to cover crop growth in 2013 impeding proper functioning of the strip

Table 1. Schedule of major field operations and data collection events at the Horticulture Research Station, Ames, IA, 2014 and 2015.

\begin{tabular}{|c|c|c|}
\hline \multirow[b]{2}{*}{ Event } & \multicolumn{2}{|c|}{ Date } \\
\hline & $2013-14$ & $2014-15$ \\
\hline Seeded cover crop & 10 Sept. 2013 & 8 Sept. 2014 \\
\hline Broccoli seeded in greenhouse & 5 May & 28 Apr. \\
\hline Tilled strips ${ }^{\mathrm{z}}$ & 14 Nov., 11 June & 12 Oct., 4 June \\
\hline Cover crop biomass samples taken & 7 May $^{y}, 3$ June $^{\mathrm{x}}$ & 13 May $^{\mathrm{y}}, 1$ June $^{\mathrm{x}}$ \\
\hline Cover crop flail mowed and tilled ${ }^{\mathrm{y}}$ & 7 May & 13 May \\
\hline Cover crop roller crimped ${ }^{\mathrm{x}}$ & 3 June & 1 June \\
\hline Preplant fertilizer applied & 11 June & 5 June \\
\hline Seedbed made using rotary tiller ${ }^{\mathrm{y}}$ & 11 June & 5 June \\
\hline Broccoli plugs transplanted & 13 June & 9 June \\
\hline Weed biomass samples taken & 2 July & 8 July \\
\hline Fertigation applications $^{\mathrm{w}}$ & 4, 17, and 26 July, 8 Aug. & $2,9,14$, and 21 July \\
\hline All plots hand weeded & 16 and 24 July & 14 July \\
\hline $\begin{array}{l}\text { Plant height, stem diameter, SPAD measurements } \\
\text { taken; leaf petiole samples collected }\end{array}$ & 8 Aug. & 26 July \\
\hline
\end{tabular}

Harvest period

11 Aug. to 12 Sept. 28 July to 3 Sept.

Strip tillage treatment only.

${ }^{\mathrm{y}}$ Conventional tillage treatment only.

${ }^{\mathrm{x}}$ Strip tillage and no tillage treatments only.

${ }^{\text {w}}$ Split fertility treatment only. tiller. The lower amount of cover crop biomass in 2014 was more completely incorporated by the strip tiller. The premise behind fall ST in the ST treatment is to eliminate cover crop in those strips which otherwise interferes and impedes the functioning of the strip tiller in the spring. Components of the strip tiller included a coulter, a subsurface shank, two concave discs, and a rolling basket. To increase down pressure of the discs for effective incorporation of the cover crop, the arms that allow the discs to float were fixed to the frame with U-bolts.

Cover crop termination date depended on the tillage treatment. In CT plots, the cover crop was mowed on 7 May 2014 and 13 May 2015, about 4 weeks before broccoli planting, using a Rhino flail mower (Alamo Group Inc., Seguin, TX) and incorporated with a rotary tiller. This early termination date allowed for decomposition of cover crop residue and was based on common practice on organic vegetable farms in the Midwest. The entire CT plot was tilled to create a seedbed just before planting, on 11 June 2014 and 5 June 2015.

The cover crop was ended in NT and ST plots on 3 June 2014 and 1 June 2015 using a 3.2-m roller-crimper (I \& J Manufacturing, Gap, PA) when cereal rye was at anthesis and the hairy vetch was in full bloom with a few young seedpods. Seedbeds were made in NT and ST plots on 11 June 2014 and 4 June 2015 after ending the cover crop with the rollercrimper. In 2014, NT plots were prepared by loosening a band of soil using the Hiniker strip tiller with the discs and rolling basket disengaged. The shank was more aggressive than was anticipated, leaving a tilled band of $10-15 \mathrm{~cm}$ in most areas. In 2015, the NT plots were prepared using a custom implement consisting of a fluted coulter followed by a minimum disturbance fertilizer knife and disc sealers to close the furrow created by the knife. This implement resulted in a tilled band of a more desirable $5.1-7.6 \mathrm{~cm}$ in width. In ST plots in both years, the previously tilled strips were tilled again with the strip tiller just before planting. 
The fertilizer applied for each fertilized treatment contained $168 \mathrm{~kg}$ total N/ha. For the preplant fertility treatment in CT plots, the entire amount of $\mathrm{N}$ was surface applied on 11 June 2014 and 4 June 2015 using dehydrated poultry manure crumbles [Chick Magic $^{\circledR}(4.0 \mathrm{~N}-1.3 \mathrm{P}-1.7 \mathrm{~K})$; S\&R Egg Farm, Palmyra, WI] and incorporated during seedbed preparation. In 2014, for ST and NT plots, poultry manure fertilizer was applied with a fertilizer hopper (MaterMacc, San Vito al Tagliamento, Italy) mounted on the Hiniker strip tiller and delivered via a tube on the backside of the shank at a depth of 10.1 $\mathrm{cm}$. In 2015, fertilizer was hand-applied and incorporated with a hoe due to malfunction of the fertilizer hopper during a narrow window of dry weather in which the fertilizer had to be applied. In the split fertility treatment, two-thirds of the $\mathrm{N}$ was applied using the poultry manure fertilizer as in the preplant fertility plots, and the remaining one-third was from liquid fish fertilizer applied via fertigation. The fish fertilizer used in 2015 [Organic Liquid Grow (5.0N-0.4P-1.7K); Peaceful Valley Farm \& Garden Supply, Grass Valley, CA] was different from the product used in 2014 [Phytamin Fish Gold ${ }^{\circledR}$ (5.0N-0.4P-1.7K); California Organic Fertilizers Inc., Hanford, CA] because Phyta$\min ^{\circledR}$ was unavailable in 2015. The split fertility subplots were fertigated four times, beginning 4 July 2014 and 2 July 2015 and repeated at 7 - to $14-d$ intervals, with frequency depending on rainfall. The liquid fertilizer was injected into the drip irrigation system using a Dosmatic SuperDos 20 fertilizer injector (Hydro Systems Co., Cincinnati, $\mathrm{OH})$. Fertigated subplots were connected to a drip header separate from preplant only and no-fertilizer subplots to prevent contamination of nonfertigated treatments. The guard rows were not fertilized.

Untreated broccoli seeds (B. oleracea var. italica 'Gypsy'; Johnny's Selected Seeds, Winslow, ME) were sown on 5 May 2014 and 28 Apr. 2015 into an organic potting medium (Mix no. 11; Beautiful Land Products, West Branch, IA) in 128-cell plug trays and grown for 4 weeks in a greenhouse before being moved outdoors to harden off. Transplants were planted on 13 June 2014 with a Holland 1500 transplanter (Holland Transplanter Co., Holland, MI) and on 9 June 2015 by hand. Hand transplanting was used in 2015 because the transplanter caused excessive disturbance to cover crop mulch in 2014 and was deemed unsuitable for use in high residue, reduced tillage conditions. The crop was irrigated as needed to achieve 1 inch of water per week using drip irrigation with the drip tape placed on the soil surface within broccoli rows. When split fertility subplots were fertigated, preplant only and no-fertilizer subplots were also irrigated to maintain parity of water supply among treatments.

Crops were scouted weekly for signs of insect pests and disease. Major insect pests were cabbage looper (Trichoplusia ni Hübner), imported cabbageworm (Pieris rapae L.), and large white caterpillars (Pieris brassicae L.) in both 2014 and 2015, and cabbage aphid (Brevicoryne brassicae L.) in 2015 only. Bacillus thuringiensis subspecies kurstaki, strain ABTS351 (DiPel PRO DF, Valent U.S.A. Corp., Walnut Creek, CA) was applied on 3 and 29 July 2014 at a rate of $0.7 \mathrm{~L} \cdot \mathrm{ha}^{-1}$ as a control for lepidopteran pests. Insecticidal soap (Safer Brand; Woodstream Corp., Lititz, PA) was applied on 8 Aug. 2014 at a rate of $9.4 \mathrm{~L} \cdot \mathrm{ha}^{-1}$ for control of aphids. Other seemingly diseased plants were submitted to the Plant and Insect Diagnostic Clinic at Iowa State University in 2014 and were found to be infected with fusarium yellows, a disease caused by the fungal pathogen Fusarium oxysporum f. sp. conglutinans.

Data collection. Aboveground cover crop biomass was determined by sampling two $50 \times 50$-cm quadrats from each whole plot immediately before termination and ovendrying at $67{ }^{\circ} \mathrm{C}$ until constant weight. Weeds were sampled on 2 July 2014 and 8 July 2015 , before the first weeding event, from two $25 \times$ $25-\mathrm{cm}$ quadrats from both the IR and BR regions of each whole plot. Weeds from each sample were counted and dried at $67^{\circ} \mathrm{C}$ until constant weight before weighing. All rows were weeded on 16 and 24 July 2014 and 14 July 2015 using a combination of hoeing and hand weeding, which translated to an average of 121,124 , and $141 \mathrm{~h} \cdot \mathrm{ha}^{-1}$ for NT, CT, and ST treatments, respectively.

Mature broccoli heads were harvested twice weekly from 11 Aug. to 12 Sept. 2014 (total of nine harvests) and 28 July to 3 Sept. 2015 (total of 10 harvests). Mature heads were harvested by cutting stems to achieve a total length of $17 \mathrm{~cm}$. Broccoli heads were then graded according to marketability (USDA, 2006) and weight and number of heads were recorded. Average diameter of broccoli heads was determined by measuring five marketable heads per subplot at each harvest. Dry weight was measured by harvesting two whole representative plants from each subplot and drying them at $67^{\circ} \mathrm{C}$ in a forced air oven until the plants reached a constant weight. Plants were sampled in the middle of the harvest period, and the head was included for the dry weight measurement.

After the final fertigation application, on 8 Aug. 2014 and 26 July 2015, five plants from the middle of each subplot row were selected for measurement of leaf chlorophyll, plant height, stem diameter, and $\mathrm{N}$ concentration of leaf tissue. Leaf $\mathrm{N}$ status was determined by analyzing dried and ground leaf petiole samples. Leaf chlorophyll, which has been shown to correlate with $\mathrm{N}$ content of corn leaves (Wood et al., 1992), was measured using a SPAD-502 Plus chlorophyll meter (Konica Minolta Sensing America Inc., Ramsey, NJ). For each of five plants, four readings were taken on the most recently developed, fully expanded leaf and averaged. Plant height was determined by measuring the distance from the soil at the base of the plant to the tip of the highest leaf. Stem diameter was measured $2 \mathrm{~cm}$ above soil using digital calipers. Leaf petiole samples were taken for $\mathrm{N}$ concentration determination according to method described by Jones and Case (1990).
Hobo temperature sensors (Onset Computer Corp., Bourne, MA) were installed at a depth of $15.2 \mathrm{~cm}$ below the soil surface between plants within one of the data rows in each whole plot. Temperature was logged at 1-h intervals from the week of transplant until after the final harvest. In addition, rainfall and air temperature were measured at a nearby weather station associated with the Iowa State University Soil Moisture Network.

Economic analysis. Enterprise budgets were created for each tillage $\times$ fertility combination to determine the profitability of each production system based on the method by Chase (2011). The economic analysis accounted for fixed and variable production costs, marketable crop yield, and selling price of $\$ 0.36 / 100 \mathrm{~g}$, the average price for broccoli in the U.S. Department of Agriculture National Fruit and Vegetable Organic Summary (USDA-AMS, 2015). Labor hours for weeding and harvest were recorded during field plot maintenance, and machinery costs were estimated using calculations described by Edwards (2015). The fuel and lubrication cost was calculated at $\$ 3.74 / \mathrm{h}$ and $\$ 0.56 / \mathrm{h}$, respectively. Based on surveys conducted in Iowa, lubrication costs on most farms averaged $\approx 15 \%$ of fuel costs. Interest rate was calculated at $5 \%$. Gross revenue was calculated by multiplying the marketable yield by the selling price of organic broccoli. Profit was calculated by subtracting fixed and variable costs of production from the gross revenue.

Data analysis. Analysis of variance (ANOVA) was conducted using the GLIMMIX procedure in SAS (version 9.3; SAS Institute, Cary, NC) to determine the effect of tillage and fertility treatments on yield, head diameter, leaf $\mathrm{N}$ concentration, leaf chlorophyll, plant height, stem diameter, cover crop and broccoli plant dry weight, soil temperature, and weed density and biomass. Block was treated as a random factor in all analyses. Data were log-transformed and square root-transformed as necessary to satisfy the homogeneity of variance and normality assumptions of ANOVA. Means on the log scale were considered medians on the original scale. With the exception of weed biomass and density analysis, means and medians were separated according to Fisher's protected least significant difference (LSD) test $(P \leq 0.05)$ using the "lsmeans" statement with Satterthwaite option. An unprotected LSD test was used for weed density and biomass to allow for analysis of the tillage $x$ region interaction. This was to accommodate our hypothesis that the degree of weed suppression by tillage treatments would depend on region (IR vs. BR).

\section{Results}

\section{Weather}

Figure 1 shows monthly rainfall and average monthly air temperature in 2014 and 2015 compared with 30 -year averages. Monthly rainfall in 2014 was 5.8 and $5.1 \mathrm{~cm}$ below average in May and July, but 18.8 and $5.3 \mathrm{~cm}$ above average in June and August, respectively. The June rainfall was 
concentrated in the second half of the month, resulting in a 3-week period of consistently saturated soil conditions starting soon after transplanting. Monthly rainfall in 2015 was 9.9 and $9.4 \mathrm{~cm}$ above average in June and August, respectively. Air temperature in 2014 was similar to the 30 -year average through most of the season, but was $2.3{ }^{\circ} \mathrm{C}$ higher than average during July. Air temperature in 2015 was $1-1.5^{\circ} \mathrm{C}$ below average from May to August, but was $2.9{ }^{\circ} \mathrm{C}$ above average in September.

\section{Cover crop performance}

In 2014, as expected, cover crop biomass in NT and ST plots was greater than in CT plots due to the delayed termination date in those treatments (Table 2). In 2014, cover crop biomass in NT and ST plots was similar, with over twice the biomass compared with CT plots. Across all treatments, cover crop biomass in 2015 was lower than in 2014, and differences between NT, ST, and CT treatments were also reduced. Carbon-to-nitrogen ratio of cover crop residue was highest for NT and ST treatments in both years (Table 2).

\section{Yield}

Marketable broccoli yield was reduced under NT and ST management in 2014, but was unaffected by tillage treatment in 2015 (Table 3). In 2014, marketable yield in CT was $31 \%$ and $46 \%$ greater than in ST and NT plots, respectively. Fertilizer had a strong effect on yield, with unfertilized treatments producing an average of $85 \%$ less than the two fertilized treatments. This reduction in yield was a result of heads maturing at a small, unmarketable size, with many plants failing to produce a head. Total yield followed the same trend as marketable yield. Average head diameter was equal among tillage treatments, and an average of $1.8 \mathrm{~cm}$ greater for preplant and split fertility treatments than for the no-fertilizer treatment. Marketable and total yields of all treatments were substantially higher in 2015, with no difference among tillage treatments. Preplant and split fertility treatments produced equal yields, which were $40 \%$ higher than yields from no-fertilizer plots. As in 2014, head diameter was equal among tillage treatments, but greater by $1.8 \mathrm{~cm}$ for fertilized treatments than the no-fertilizer treatment. There were no significant interactions for yield or head diameter in either year.

\section{Plant growth}

Leaf $N$ and SPAD. There was no difference in leaf $\mathrm{N}$ or SPAD among tillage treatments in either year (Table 4). In 2014, leaf $\mathrm{N}$ was similar among fertility treatments, but SPAD reading of plants in fertilized plots was an average of 7.1 points higher than of plants in unfertilized plots. In 2015, both leaf $\mathrm{N}$ and SPAD readings were higher for fertilized than unfertilized treatments. There was a strong correlation (Pearson's $r=0.971, P<$ 0.0001 ) between leaf $\mathrm{N}$ and SPAD in 2014, and a weak correlation (Pearson's $r=0.374$, $P=0.0247$ ) in 2015 .

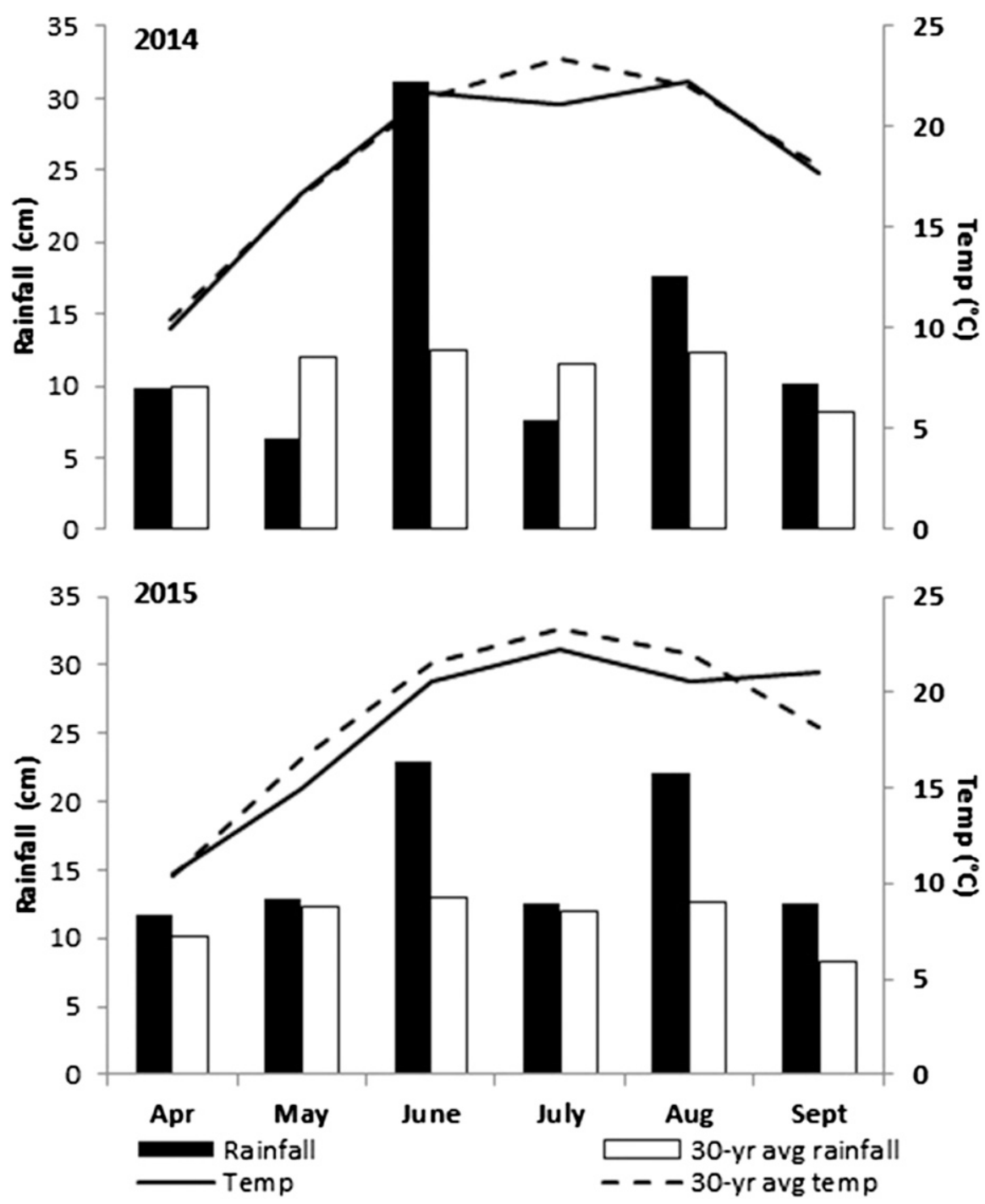

Fig. 1. Monthly rainfall and mean air temperature in 2014 and 2015 in Ames, IA, compared with the 30-year average. Weather data were obtained from the Iowa State University Soil Moisture Network.

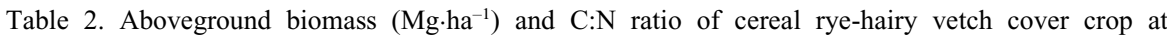
termination ${ }^{z}$, Ames, IA, 2014 and 2015.

\begin{tabular}{|c|c|c|c|c|}
\hline \multirow[b]{2}{*}{ Treatment } & \multicolumn{2}{|c|}{2014} & \multicolumn{2}{|c|}{2015} \\
\hline & Biomass $^{y}$ & $\mathrm{C}: \mathrm{N}$ ratio & Biomass & $\mathrm{C}: \mathrm{N}$ ratio \\
\hline $\mathrm{CT}$ & $6.2 b^{x}$ & $23: 1 \mathrm{~b}$ & $6.2 \mathrm{~b}$ & $25: 1 b$ \\
\hline ST & $13.0 \mathrm{a}$ & $42: 1 \mathrm{a}$ & $9.3 \mathrm{a}$ & $31: 1 \mathrm{a}$ \\
\hline NT & $11.6 \mathrm{a}$ & $43: 1 \mathrm{a}$ & $7.0 \mathrm{~b}$ & $34: 1 \mathrm{a}$ \\
\hline Significance & $* * *$ & $* * *$ & ** & $*$ \\
\hline
\end{tabular}

$\mathrm{C}: \mathrm{N}=$ carbon-to-nitrogen ratio; $\mathrm{CT}=$ conventional tillage; $\mathrm{ST}=$ strip tillage; $\mathrm{NT}=$ no tillage.

${ }^{\mathrm{z} D a t e s}$ of termination: CT = 7 May 2014 and 13 May 2015; NT and ST = 3 June 2014 and 1 June 2015. ${ }^{\mathrm{y}}$ Biomass data were log-transformed for homogeneity of variance and normality before analysis and back transformed for presentation.

${ }^{\mathrm{x}}$ Means within the same column followed by the same letter are not significantly different according to Fisher's protected least significant difference $(P \leq 0.05)$.

$*, * *, * * *$ Significant at $P \leq 0.05,0.01$, or 0.001 , respectively, based on $F$ test.

Plant height. In 2014, height of broccoli plants was 6.9 and $11 \mathrm{~cm}$ greater in CT than in ST and NT plots, respectively (Table 4). Plant height in preplant and split fertility plots was equal, but an average of $14.7 \mathrm{~cm}$ greater than in no-fertilizer plots. A tillage $\times$ fertility interaction $(P=0.0003)$ occurred for plant height, whereby there was no difference between CT and NT when using preplant fertilization. In 2015, plant height was equal across tillage treatments, but an average of $8.1 \mathrm{~cm}$ less for no-fertilizer than for preplant or split fertility treatments.

Stem diameter. In 2014, stem diameter of broccoli plants was greater in CT than in NT plots, but neither was different from that in ST plots. There was no difference in stem diameter among tillage treatments in 2015 
Table 3. Marketable and total broccoli yield and average marketable broccoli head diameter as affected by tillage and fertility treatments, Ames, IA, 2014 and 2015 .

\begin{tabular}{|c|c|c|c|c|c|c|}
\hline \multirow[b]{2}{*}{ Treatment } & \multicolumn{3}{|c|}{2014} & \multicolumn{3}{|c|}{2015} \\
\hline & $\overline{\text { Marketable yield }\left(\mathrm{Mg} \cdot \mathrm{ha}^{-1}\right)}$ & Total yield $\left(\mathrm{Mg} \cdot \mathrm{ha}^{-1}\right)$ & Head diam $(\mathrm{cm})$ & $\overline{\text { Marketable yield }\left(\mathrm{Mg} \cdot \mathrm{ha}^{-1}\right)}$ & Total yield $\left(\mathrm{Mg} \cdot \mathrm{ha}^{-1}\right)$ & Head diam $(\mathrm{cm})$ \\
\hline $\mathrm{CT}$ & $5.9 \mathrm{a}^{\mathrm{z}}$ & $7.1 \mathrm{a}$ & 8.6 & 20.6 & 21.3 & 11.3 \\
\hline NT & $4.1 \mathrm{~b}$ & $3.9 \mathrm{~b}$ & 8.5 & 20.4 & 19.8 & 11.1 \\
\hline Significance & $* * *$ & ** & NS & NS & NS & NS \\
\hline \multicolumn{7}{|l|}{ Fertility (F) } \\
\hline Preplant & $6.4 \mathrm{a}$ & $7.2 \mathrm{a}$ & $9.1 \mathrm{a}$ & $22.6 \mathrm{a}$ & $23.5 \mathrm{a}$ & $11.7 \mathrm{a}$ \\
\hline Significance & $* * *$ & $* * *$ & * & $* * *$ & $* * *$ & $* * *$ \\
\hline $\mathrm{T} \times \mathrm{F}$ & NS & NS & NS & NS & NS & NS \\
\hline
\end{tabular}

$\mathrm{CT}=$ conventional tillage; $\mathrm{ST}=$ strip tillage; $\mathrm{NT}=$ no tillage; Preplant $=$ only preplant fertilizer; Split $=$ two-thirds of $\mathrm{N}$ from preplant fertilizer and one-third from fertigation; No fert = unfertilized control.

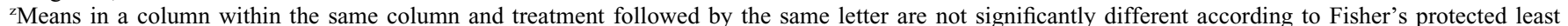
significant difference $(P \leq 0.05)$.

${ }_{\mathrm{NS}, *, * *, * * *}$ Nonsignificant or significant at $P \leq 0.05,0.01$, or 0.001 , respectively, based on $F$ test.

Table 4. Leaf nitrogen (N), SPAD readings, plant height, stem diameter, and dry weight of broccoli plants as affected by tillage and fertility treatments, Ames, IA, 2014 and $2015 .^{2}$

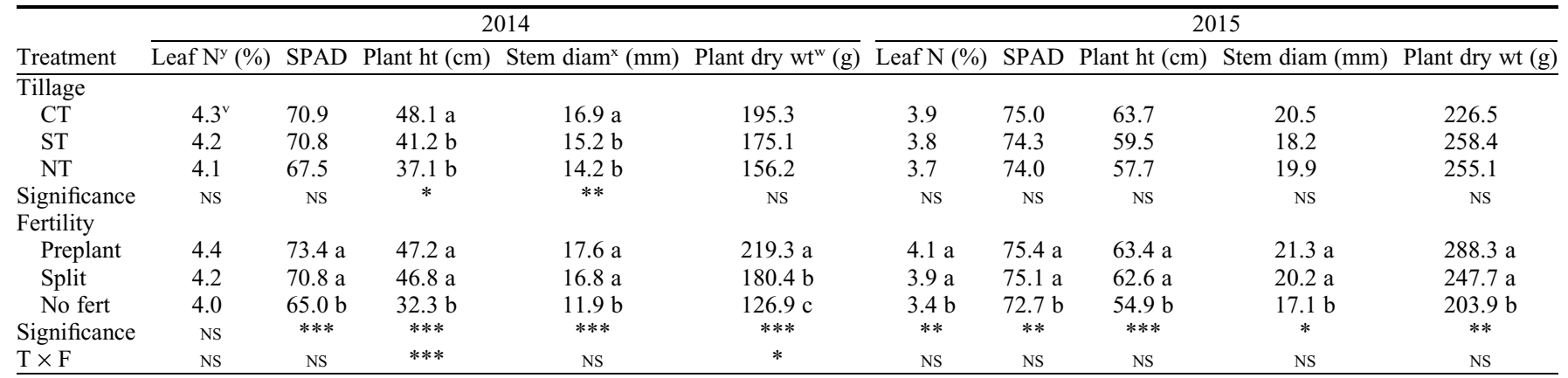

$\mathrm{CT}=$ conventional tillage; $\mathrm{ST}=$ strip tillage; $\mathrm{NT}=$ no tillage; Preplant $=$ only preplant fertilizer; Split $=$ two-thirds of $\mathrm{N}$ from preplant fertilizer and one-third from fertigation; No fert $=$ unfertilized control.

${ }^{z}$ Measurements were taken on 8 Aug. 2014 and 26 July 2015, after the final fertigation event.

${ }^{\mathrm{y}}$ Percent $\mathrm{N}$ of dried and ground leaf petioles. Samples were composed of 20 broccoli leaves.

${ }^{x}$ Diameter of stem measured $2 \mathrm{~cm}$ above soil level.

"Dry weight of two whole plants.

'Means in a column within the same column and treatment followed by the same letter are not statistically different according to Fisher's protected least significant difference $(P \leq 0.05)$.

Ns, *, **, *** Nonsignificant or significant at $P \leq 0.05,0.01$, or 0.001 , respectively, based on $F$ test.

(Table 4). In both years, stem diameter was equal for preplant and split fertility treatments, but stem diameter averaged 5.3 and $3.7 \mathrm{~mm}$ greater than the no-fertilizer treatment in 2014 and 2015, respectively.

Plant biomass. There was no effect of tillage on broccoli plant dry weight in either year, but fertilization had a strong effect in both years (Table 4). In 2014, plants in preplant fertility plots weighed $18 \%$ and $42 \%$ more than those in split and nofertilizer plots, respectively. In 2015, plant dry weight for preplant and split fertility treatments was equal, but was reduced by $24 \%$ in the no-fertilizer treatment. A tillage $\times$ fertility interaction $(P=0.016)$ occurred for plant dry weight, whereby the no-fertilizer treatment had greater dry weight than the split fertility treatment in CT plots, but lower dry weight in NT and ST plots.

\section{Soil temperature}

Conventional tillage generally increased soil temperature throughout the season, which was divided into three periodsdenoted "early" (14 June to 14 July 2014;
17 June to 12 July 2015), "mid" (15 July to 13 Aug. 2014; 13 July to 6 Aug. 2015), and "late" (14 Aug. to 15 Sept. 2014; 7 Aug. to 2 Sept. 2015) for analysis (Table 5). The season was divided into these three periods to overlap with broccoli growth stages of early establishment, active growth phase, and fruiting phase). This helps to interpret soil temperature data with plant growth phases. During the early period in both years, CT increased average daily minimum, mean, and maximum soil temperatures by 0.8 to $3.8^{\circ} \mathrm{C}$, as compared with ST and NT. There was no difference in early-season temperature between ST and NT except in 2015 when ST had 0.6 and $1.1^{\circ} \mathrm{C}$ higher mean and maximum temperatures, respectively. During midperiod, CT increased average daily minimum, mean, and maximum soil temperatures by 0.6 to $2.3^{\circ} \mathrm{C}$, as compared with ST or NT, with the exception of minimum temperature in 2015, when there was no difference among treatments. Compared with NT, ST increased midperiod minimum temperature by $0.5^{\circ} \mathrm{C}$ in 2014 , but was not different from NT in midperiod mean or maximum temperature in either year. During the late period in both years, there was no effect of tillage treatment on average daily minimum temperature, but $\mathrm{CT}$ increased mean and maximum temperatures by 0.8 to $2.4^{\circ} \mathrm{C}$, as compared with ST or NT.

\section{Weed suppression}

The primary weed species present in the 2014 field site were common purslane (Portulaca oleracea L.), redroot pigweed (Amaranthus retroflexus L.), and yellow foxtail (Setaria pumila Poir.). The dominant weed species in the 2015 site were witchgrass (Panicum capillare L.), red clover (Trifolium pratense L.), and white clover (Trifolium repens L.). In 2014, the cover crop mulch provided effective weed suppression in NT and ST plots. Weed biomass and density were highest in IRand BR regions of CT plots and the IR region of ST plots (Table 6). The BR region of NT and ST plots had negligible weed growth. In 2015, weed biomass and density were highest in the BR region of CT plots and lowest in the BR region of ST plots. However, weed biomass and density were 
Table 5. Effects of NT, ST, and CT on average minimum, mean, and maximum soil temperature $\left({ }^{\circ} \mathrm{C}\right)$ at 6 -inch depth during early ${ }^{\mathrm{z}}$, mid ${ }^{\mathrm{y}}$, and late ${ }^{\mathrm{x}}$ seasons of broccoli production, Ames, IA, 2014 and 2015.

\begin{tabular}{|c|c|c|c|c|c|c|c|c|c|}
\hline \multirow[b]{2}{*}{ Treatment } & \multicolumn{3}{|c|}{ Minimum } & \multicolumn{3}{|c|}{ Mean } & \multicolumn{3}{|c|}{ Maximum } \\
\hline & Early & Mid & $\overline{\text { Late }}$ & Early & Mid & Late & Early & Mid & Late \\
\hline \multicolumn{10}{|c|}{2014} \\
\hline $\mathrm{CT}$ & $20.2 \mathrm{a}^{\mathrm{w}}$ & $20.4 \mathrm{a}$ & 19.6 & $22.3 \mathrm{a}$ & $22.6 \mathrm{a}$ & $21.7 \mathrm{a}$ & $24.8 \mathrm{a}$ & $24.9 \mathrm{a}$ & $24.3 \mathrm{a}$ \\
\hline ST & $19.4 \mathrm{~b}$ & $19.8 \mathrm{~b}$ & 19.6 & $20.9 \mathrm{~b}$ & $21.2 \mathrm{~b}$ & $20.9 \mathrm{~b}$ & $22.7 \mathrm{~b}$ & $22.7 \mathrm{~b}$ & $22.4 \mathrm{~b}$ \\
\hline NT & $19.1 \mathrm{~b}$ & $19.3 \mathrm{c}$ & 19.2 & $20.7 \mathrm{~b}$ & $20.8 \mathrm{~b}$ & $20.6 \mathrm{~b}$ & $22.5 \mathrm{~b}$ & $22.6 \mathrm{~b}$ & $22.3 \mathrm{~b}$ \\
\hline Significance & $* * *$ & $* * *$ & NS & $* * *$ & $* *$ & $*$ & $* * *$ & $*$ & $* * *$ \\
\hline \multicolumn{10}{|c|}{2015} \\
\hline $\mathrm{CT}$ & $20.6 \mathrm{a}$ & 22.3 & 19.9 & $23.0 \mathrm{a}$ & $23.8 \mathrm{a}$ & $22.0 \mathrm{a}$ & $25.9 \mathrm{a}$ & $25.6 \mathrm{a}$ & $24.7 \mathrm{a}$ \\
\hline ST & $19.5 \mathrm{~b}$ & 21.8 & 19.7 & $21.2 \mathrm{~b}$ & $22.9 \mathrm{~b}$ & $21.2 \mathrm{~b}$ & $23.2 \mathrm{~b}$ & $24.1 \mathrm{~b}$ & $22.9 \mathrm{~b}$ \\
\hline NT & $19.3 \mathrm{~b}$ & 21.8 & 19.6 & $20.6 \mathrm{c}$ & $22.8 \mathrm{~b}$ & $20.9 \mathrm{~b}$ & $22.1 \mathrm{c}$ & $23.9 \mathrm{~b}$ & $22.3 \mathrm{~b}$ \\
\hline Significance & $* *$ & NS & NS & $* * *$ & $* *$ & $* * *$ & $* * *$ & $* *$ & $* *$ \\
\hline
\end{tabular}

$\mathrm{CT}=$ conventional tillage; $\mathrm{ST}=$ strip tillage; $\mathrm{NT}=$ no tillage.

${ }^{z}$ Early season: 14 June to 14 July 2014; 17 June to 12 July 2015.

y Midseason: 15 July to 13 Aug. 2014; 13 July to 6 Aug. 2015.

${ }^{\mathrm{x}}$ Late season: 14 Aug. to 15 Sept. 2014; 7 Aug. to 2 Sept. 2015.

${ }^{w}$ Means within column and year followed by the same letter are not significantly different according to Fisher's protected least significant difference $(P \leq 0.05)$.

Ns, $*, * *, * * *$ Nonsignificant or significant at $P \leq 0.05,0.01$, or 0.001 , respectively, based on $F$ test.

Table 6. IR and BR weed biomass $\left(\mathrm{g} \cdot \mathrm{m}^{-2}\right)$ and density (weeds $\left./ \mathrm{m}^{2}\right)$ as affected by three tillage treatments, Ames, IA, 2014 and 2015 .

\begin{tabular}{|c|c|c|c|c|c|}
\hline \multirow[b]{2}{*}{ Tillage $^{y}$} & \multirow[b]{2}{*}{ Region } & \multicolumn{2}{|c|}{2014} & \multicolumn{2}{|c|}{2015} \\
\hline & & Biomass & Density & Biomass & Density \\
\hline \multirow[t]{2}{*}{$\overline{\mathrm{CT}}$} & BR & $1.1 \mathrm{ab}^{\mathrm{y}}$ & $129.9 \mathrm{a}$ & $24.4 \mathrm{a}$ & $113.6 \mathrm{a}$ \\
\hline & IR & $1.8 \mathrm{a}$ & $171.5 \mathrm{a}$ & $4.3 \mathrm{~b}$ & $57.4 \mathrm{ab}$ \\
\hline \multirow[t]{2}{*}{ ST } & $\mathrm{BR}$ & $0.3 \mathrm{c}$ & $1.3 \mathrm{~b}$ & $0.6 \mathrm{c}$ & $4.5 \mathrm{c}$ \\
\hline & IR & $1.0 \mathrm{ab}$ & $124.2 \mathrm{a}$ & $1.2 \mathrm{bc}$ & $29.8 \mathrm{bc}$ \\
\hline \multirow[t]{2}{*}{ NT } & $\mathrm{BR}$ & $0.0 \mathrm{c}$ & $0.0 \mathrm{~b}$ & $2.0 \mathrm{bc}$ & $29.8 \mathrm{bc}$ \\
\hline & IR & $0.5 \mathrm{bc}$ & $53.9 \mathrm{ab}$ & $2.4 \mathrm{bc}$ & $36.9 \mathrm{bc}$ \\
\hline
\end{tabular}

$\mathrm{CT}=$ conventional tillage; $\mathrm{ST}=$ strip tillage; $\mathrm{NT}=$ no tillage; $\mathrm{IR}=$ in-row; $\mathrm{BR}=$ between-row

${ }^{2}$ Weeds were sampled on 2 July 2014 and 8 July 2015.

${ }^{y}$ Means within a column followed by the same letter are not significantly different according to the unprotected least significant difference $(P \leq 0.05)$.

similar in the IR regions of ST and CT plots and both regions of NT plots.

\section{Profitability}

Treatments with the highest profits were CT using preplant fertilization in 2014 and CT using split fertilization in 2015 (Table 7), although profit from the ST-preplant treatment was only $2.3 \%$ lower than the CT-split treatment in 2015. In both years, preharvest labor costs were lowest for the NT treatment due to reduced weeding labor, and input costs were higher for split than preplant fertility treatments because the fish fertilizer cost per unit of $\mathrm{N}$ was greater than the dehydrated poultry manure. Total costs varied among treatments by a maximum of $\$ 730$ in 2014 and $\$ 922$ in 2015. Given that costs were similar among tillage treatments, differences in profit can be largely attributed to differences in yield.

\section{Discussion and Conclusions}

Use of cover crops is already standard practice on most organic vegetable farms, but few organic growers in the Upper Midwest have experimented with reducing tillage. Our results suggest that NT or ST can be used for production of broccoli. In combination with cover crops tillage treatment affected measures of plant $\mathrm{N}$ status, but these differences did not always correspond with yield. Other factors, such as fertilizer and weed management, may also affect crop productivity in reduced tillage systems. Our data show that fertilizers that are low in inorganic $\mathrm{N}$, such as dehydrated poultry manure, may be most effective if applied at the full rate before planting, and adequate control of annual weeds between the rows can be achieved with heavy cover crop residue. However, weed growth within the crop row may be substantial and difficult to control in a rolled cover crop system.

There was a large disparity in yield between years, with higher yields for all treatments in 2015. Three factors may explain why this occurred. First, whereas the preceding crop in 2014 was nonleguminous cover crops followed by 3 -month fallow, the preceding crop in the 2015 site was alfalfa, which likely increased $\mathrm{N}$ availability to the broccoli plants. Second, the occurrence of fusarium yellows disease in 2014 stunted plant growth, and third, the concentrated rainfall in the second half of June 2014 caused a 3-week period of consistently saturated soil starting soon after transplanting (Fig. 1). Plants in the NT and ST likely dried more slowly due to the presence of cover crop residue. Since the broccoli was planted relatively late to accommodate the maturation date of the cover crops for roller-crimper termination, the plants experienced high temdisease caused by $F$. oxysporum f. sp. conglutinans (Bosland et al., 1988). Average air temperature in the month of July for 2014 was $21.1{ }^{\circ} \mathrm{C}$ (Fig. 1). While there was no peratures known to increase the severity of difference among tillage treatments in 2015, yield of broccoli was lower in NT and ST than in CT plots during the 2014 growing season. We suspect that the effect of tillage on broccoli yield in 2014 may have been confounded by the occurrence of fusarium yellows. At the time of onset of disease symptoms in early July, plants in CT plots were larger and darker in color than plants in NT and ST plots. This early vigor of plants in CT plots may have caused differences among treatments in susceptibility to plant disease.

Nitrogen availability has previously been suggested as a limiting factor in cover cropbased reduced tillage systems (Leavitt et al., 2011; Wells et al., 2013). Leaf chlorophyll, as measured by the SPAD meter, was not correlated with marketable yield in 2014, but was in 2015 (Pearson's $r=0.501, P=$ $0.0019)$. Yield, SPAD reading, and leaf $\mathrm{N}$ concentration were all lower in unfertilized plots than in preplant and split fertility plots each year, reflecting a strong correlation between $\mathrm{N}$ and crop yield. In contrast, despite a yield reduction in NT and ST treatments in 2014, N status was similar among tillage treatments in both years. The lack of a positive relationship between yield and $\mathrm{N}$ status in 2014 may be explained by leaf $\mathrm{N}$ concentrations from all tillage and fertility treatments being in the optimal ranges for broccoli of $3.0-4.5 \mathrm{~g} \cdot \mathrm{kg}^{-1} \mathrm{~N}$ (Hartz and Hochmuth, 1996). This would indicate that $\mathrm{N}$ may not have been limiting for NT and ST treatments in this study. However, because leaf $\mathrm{N}$ measurements were taken at only one point in time (7-8 weeks after planting), it is possible that plants in NT and ST treatments experienced $\mathrm{N}$ deficiency early in the 2014 season (Schellenberg et al., 2009).

Despite measures of plant $\mathrm{N}$ status indicating that plants in all treatments received sufficient $\mathrm{N}$, crop yield was affected by the fertility treatment (Table 4). We hypothesized that splitting the fertilizer application between a preplant application of dehydrated poultry manure and successive applications of fish emulsion through drip irrigation would be most effective in supplying plantavailable $\mathrm{N}$ during the period of rapid 
Table 7. Enterprise budgets for organically produced broccoli in 2014 and 2015 as affected by tillage and fertility treatment (US\$/ha).

\begin{tabular}{|c|c|c|c|c|c|c|c|c|c|c|c|c|}
\hline & \multicolumn{6}{|c|}{2014} & \multicolumn{6}{|c|}{2015} \\
\hline & \multicolumn{3}{|c|}{ Preplant $^{z}$} & \multicolumn{3}{|c|}{ Split $^{2}$} & \multicolumn{3}{|c|}{ Preplant } & \multicolumn{3}{|c|}{ Split } \\
\hline & $\mathrm{CT}$ & ST & NT & $\mathrm{CT}$ & ST & NT & $\mathrm{CT}$ & ST & NT & $\mathrm{CT}$ & ST & NT \\
\hline Broccoli yield (t $\left.\cdot \mathrm{ha}^{-1}\right)$ & 7.3 & 4.4 & 6.8 & 7.3 & 4.6 & 4.6 & 19.6 & 22.5 & 21.3 & 23.3 & 21.4 & 19.1 \\
\hline Gross revenue & 26,807 & 16,088 & 24,948 & 26,812 & 16,822 & 16,809 & 72,135 & 82,859 & 78,344 & 85,794 & 78,571 & 70,441 \\
\hline Interest expense & 531 & 492 & 521 & 591 & 556 & 541 & 781 & 830 & 781 & 907 & 867 & 803 \\
\hline Seed and inputs ${ }^{\mathrm{y}}$ & 3,156 & 3,156 & 3,156 & 4,141 & 4,141 & 4,141 & 3,207 & 3,207 & 3,207 & 4,196 & 4,196 & 4,196 \\
\hline Preharvest labor ${ }^{\mathrm{x}}$ & 2,140 & 2,338 & 2,115 & 2,140 & 2,338 & 2,115 & 2,619 & 2,560 & 2,115 & 2,619 & 2,560 & 2,115 \\
\hline Harvest cost ${ }^{v}$ & 3,573 & 2,713 & 3,425 & 3,573 & 2,773 & 2,773 & 7,196 & 8,051 & 7,690 & 8,288 & 7,707 & 7,060 \\
\hline Ownership costs ${ }^{v}$ & 1,883 & 1,826 & 1,821 & 1,883 & 1,826 & 1,821 & 1,883 & 1,826 & 1,821 & 1,883 & 1,826 & 1,821 \\
\hline Total costs & 11,280 & 10,524 & 11,036 & 12,328 & 11,634 & 11,392 & 15,686 & 16,475 & 15,612 & 17,890 & 17,154 & 15,993 \\
\hline Profit & 15,527 & 5,564 & 13,912 & 14,483 & 5,188 & 5,418 & 56,449 & 66,384 & 62,732 & 67,904 & 61,417 & 54,448 \\
\hline
\end{tabular}

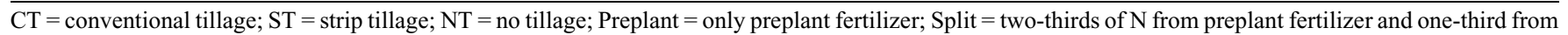
fertigation.

yBoccoli and cover crop seed, potting mix, fertilizer, drip tape, and insecticide.

${ }^{x}$ Labor for seeding flats, setting up irrigation, spraying insecticide, and hand-weeding. Based on a $\$ 12 / \mathrm{h}$ wage ( $\$ 10 / \mathrm{h}$ wage plus payroll taxes).

${ }^{\mathrm{w}}$ Cost of waxed boxes and labor for harvest, washing, and packing. Labor based on a wage of $\$ 12 / \mathrm{h}$.

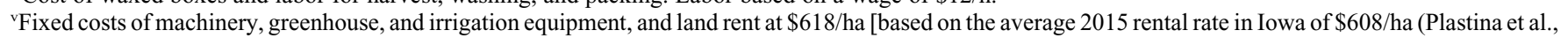
2015)].

vegetative growth following transplanting. Both fish fertilizers used in this study contained $5 \%$ total $\mathrm{N}$ with $4.1 \%$ to $4.25 \%$ water soluble $\mathrm{N}$, so we expected that the use of fertigation in the split fertility treatment would increase yields. However, there was no difference in the yield between preplant and split fertility treatments in either year.

To achieve equal total $\mathrm{N}$ in each fertilizer treatment, split treatments had to be fertilized with a lower preplant rate of dehydrated poultry manure, the difference being made up through fertigation beginning 3 weeks after planting. Hadas et al. (1983) found that pelleted poultry manure incorporated into soil and incubated at $25{ }^{\circ} \mathrm{C}$ released $42 \%$ of organic $\mathrm{N}$ through mineralization after 1 week. Mineralization of $\mathrm{N}$ from poultry manure increased to only $50 \%$ after $60-90 \mathrm{~d}$. Because the preplant fertility treatment received $168.1 \mathrm{~kg} \cdot \mathrm{ha}^{-1}$ of poultry manure, compared with $112.1 \mathrm{~kg} \cdot \mathrm{ha}^{-1}$ for the split fertility treatment, those plots may have received the equivalent of $23.5 \mathrm{~kg} \cdot \mathrm{ha}^{-1}$ more $\mathrm{N}$ than the split fertility plots during the first month of growth. The subsequent application of water-soluble $\mathrm{N}$ to split fertility plots via fertigation during weeks 3-7 after planting did not lead to higher yields than in preplant fertility plots. Applying granular fertilizer, a single time before planting is simpler than making repeated applications of fish fertilizer using a fertilizer injector, making the preplant only system more desirable from a management standpoint. Furthermore, dehydrated poultry manure is less expensive than fish fertilizer per unit of $\mathrm{N}$, as reflected in our economic analysis, so we recommend the use of dehydrated poultry manure as the sole $\mathrm{N}$ source for broccoli production using rolled cover crop mulch.

Cover crop biomass in NT and ST plots exceeded that observed in CT plots due to the later cover crop termination date in NT and ST systems. Weed suppression by the cover crop mulch was mostly effective due to the large amount of biomass produced. Cover crop biomass exceeded the $8000 \mathrm{~kg} \cdot \mathrm{ha}^{-1}$ level identified by Teasdale and Mohler (2000) as the minimum biomass necessary to inhibit emergence of annual weeds. Two factors that may have favored high biomass production in our study are the soil type and seeding date. The relatively high organic matter soil at the experimental sites $(2.3 \%$ to $3.5 \%$ in 2014 and $2.7 \%$ to $4.1 \%$ in 2015 , data not shown) likely provided sufficient nutrients to the cover crop despite the lack of supplemental fertilization. In fact, cover crop biomass was not increased in the second season when the preceding crop was alfalfa. In a field experiment in Pennsylvania, Mirsky et al. (2013) found that cereal rye biomass ranged from 1,615 to 12,600 $\mathrm{kg} \cdot \mathrm{ha}^{-1}$ when seeded in $10-\mathrm{d}$ intervals from late August to mid-October. The early September seeding date used in the present experiment likely played a role in increasing biomass. Ryan et al. (2011) determined that increasing cereal rye seeding rate did not increase biomass, but did improve weed control by the subsequently rolled cover crop. They suggested that the improvement in weed control achieved by increasing the rye seeding rate up to $209.6 \mathrm{~kg} \cdot \mathrm{ha}^{-1}$ was likely a result of increased early-spring groundcover. The seeding rate used in the present study $\left(112.1 \mathrm{~kg} \cdot \mathrm{ha}^{-1}\right)$ was higher than is typically recommended for cereal rye in a green manure system (Clark, 2007), but lower than the rates that were found to maximize groundcover in early spring. Given a fertile soil and an early seeding date, a moderate seeding rate of $112.1 \mathrm{~kg} \cdot \mathrm{ha}^{-1}$ can be used to achieve good annual weed suppression in a rolled cover crop system.

Unlike annual weeds, perennial weeds, which were present in the 2015 site, were not suppressed as effectively by the cover crop mulch as indicated by the lack of a difference in weed biomass between IR and BR regions of NT and ST plots in 2015. The combination of larger, perennial weeds and a delayed sampling date (6 d later in 2015) also explains the greater weed biomass across all treatments in 2015. However, with sufficient cover crop biomass and a field with lower perennial weed populations, the principal weed management challenge in organically managed, cover crop-based reduced tillage systems is the control of IR weeds. In NT systems, IR weed pressure may be low if the crop can be planted with minimal disturbance to the cover crop mulch. However, few commercially available no-till transplanters exist in the United States, so most growers may need to use a two-pass system-like the one used in the present study-to transplant through a rolled cover crop mulch. This narrow tillage pass with a shank to loosen soil ahead of transplanting may inevitably disturb a wider band of soil than is desired for minimization of weed seed germination, yet this disturbance may be necessary for proper functioning of a conventional transplanter. Use of a mechanical transplanter equipped with a coulter and shank mounted ahead of the planting unit, or a roller-crimper with a shank mounted behind it, as described by Ciaccia et al. (2016), may allow for establishment of vegetable transplants with minimal disturbance to the mulch, thus maximizing the suppressive effect of the rolled cover crop.

The findings of this study contribute to the growing body of research that shows the potential for reduced tillage systems to produce yields equivalent to CT. However, the yield reduction observed in 2014 prevents us from drawing strong conclusions about the consistency of high yields under NT and ST. We have shown that despite increasing soil temperature, ST may not increase yield over NT. Furthermore, the additional field operations required to till the strips twice and the potential for increased weed pressure as a result of exposed IR soil are significant drawbacks to the use of ST in organic systems.

Partial budget analysis demonstrated that yield plays a critical role in influencing net returns. Based on our assumptions and production system, profitability within NT systems is heavily influenced by fertilizer application method. Given the absence of tillage in NT system, it is better to apply fertilizers preplant rather than in split applications. In 2014, returns were always higher in CT system; however, one has to weigh economic risks from conservation tillage systems against the positive benefits of soil erosion prevention and improvements in soil 
quality in NT and ST production (Schillinger et al., 2007).

Cover crop-based reduced tillage is an area worthy of further exploration by researchers. There is mounting evidence that NT and ST using winter annual cover crops can be successful in the production of certain crops, but trials should be expanded to evaluate potential application to a broader diversity of vegetable crops. Such data would be of great value to the rapidly growing population of diversified vegetable farmers. Furthermore, organic NT research has focused heavily on cereal rye, which must be ended at anthesis (Ashford and Reeves, 2003), thus restricting application to cash crops that should be planted early in the summer season. Cereal rye anthesis typically occurs in late-May to early-June in the Upper Midwest, outside of the normal planting dates for early spring- or late summer-planted successions of many cool-season vegetable crops. To increase adoption, future research should evaluate spring- and summer-planted cover crops that mature and can be ended mechanically at different times of the year.

\section{Literature Cited}

Abdul-Baki, A.A., J.R. Teasdale, R. Korcak, D.J. Chitwood, and R.N. Huettel. 1996. Freshmarket tomato production in a low-input alternative system using cover-crop mulch. HortScience 31:65-69.

Ashford, D.L. and D.W. Reeves. 2003. Use of a mechanical roller-crimper as an alternative kill method for cover crops. Amer. J. Alt. Agr. 18:37-45.

Aulakh, M.S., D.T. Walters, J.W. Doran, D.D. Francis, and A.R. Mosier. 1991. Crop residue type and placement effects on denitrification and mineralization. Soil Sci. Soc. Amer. J. 55:1020-1025.

Baker, J.M., T.E. Ochsner, R.T. Venterea, and T.J. Griffis. 2007. Tillage and soil carbon sequestration: What do we really know? Agr. Ecosyst. Environ. 118:1-5.

Berry, P.M., R. Sylvester-Bradley, L. Philipps, D.J. Hatch, S.P. Cuttle, F.W. Rayns, and P. Gosling. 2002. Is the productivity of organic farms restricted by the supply of available nitrogen? Soil Use Mgt. 18:248-255.

Bosland, P.W., P.H. Williams, and R.H. Morrison. 1988. Influence of soil temperature on the expression of yellows and wilt of crucifers by Fusarium oxysporum. Plant Dis. 72:777-780.

Brainard, D.C. and D.C. Noyes. 2012. Strip tillage and compost influence carrot quality, yield, and net returns. HortScience 47:1073-1079.

Brainard, D.C., E. Peachey, E.R. Haramoto, J.M. Luna, and A. Rangarajan. 2013. Weed ecology and nonchemical management under striptillage: Implications for northern U.S. vegetable cropping systems. Weed Technol. 27:218-230.

Chase, C. 2011. Iowa fruit \& vegetable production budgets. 6 Oct. 2015. <http://www.extension. iastate.edu/agdm/crops/html/a1-17.html $>$.

Ciaccia, C., S. Canali, G. Campanelli, E. Testani, F. Montemurro, F. Leteo, and K. Delate. 2016. Effect of roller-crimper technology on weed management in organic zucchini production in a Mediterranean climate zone. Renewable Agr. Food Systems 31:111-121.

Clark, A. 2007. Managing cover crops profitably. 3rd ed. Sustainable Agriculture Research and Education, Beltsville, MD.

Creamer, N.G., M.A. Bennett, B.R. Stinner, and J. Cardina. 1996a. A comparison of four processing tomato production systems differing in cover crop and chemical inputs. J. Amer. Soc. Hort. Sci. 121:559-568.

Creamer, N.G., M.A. Bennett, B.R. Stinner, J. Cardina, and E.E. Regnier. 1996b. Mechanisms of weed suppression in cover crop-based production systems. HortScience 31:410-413.

Delate, K., C. Cambardella, and A. McKern. 2008. Effects of organic fertilization and cover crops on an organic pepper system. HortTechnology 18:215-226.

Delate, K., D. Cwach, and C. Chase. 2012. Organic no-tillage system effects on soybean, corn and irrigated tomato production and economic performance in Iowa, USA. Renew. Agr. Food Syst. 27:49-59.

Díaz-Pérez, J.C., J. Silvoy, S. Phatak, J. Ruberson, and R. Morse. 2008. Effect of winter cover crops and no-till on the yield of organicallygrown bell pepper (Capsicum annuum L.). In: R. Prange and S. Bishop (eds.). Proc. XXVII IHC-S11 Sustainability through integrated and organic horticulture. Acta. Hort. 767:243-247.

Edwards, W. 2015. Estimating farm machinery costs. 6 Oct. 2015. <https://www.extension. iastate.edu/agdm/crops/html/a3-29.html $>$.

Gaskell, M. and R. Smith. 2007. Nitrogen sources for organic vegetable crops. HortTechnology 17:431-441.

Hadas, A., B. Bar-Yosef, S. Davidov, and M. Sofer. 1983. Effect of pelleting, temperature, and soil type on mineral nitrogen release from poultry and dairy manures. Soil Sci. Soc. Amer. J. 47:1129-1133.

Haramoto, E.R. and D.C. Brainard. 2012. Strip tillage and oat cover crops increase soil moisture and influence $\mathrm{N}$ mineralization patterns in cabbage. HortScience 47:1596-1602.

Hartz, T.K. and G.J. Hochmuth. 1996. Fertility management of drip-irrigated vegetables. HortTechnology 6:168-172.

Johnson, M.D. and B. Lowery. 1985. Effect of three conservation tillage practices on soil temperature and thermal properties. Soil Sci. Soc. Amer. J. 49:1547-1552.

Jones, J.J.B. and V.W. Case. 1990. Sampling, handling and analyzing plant tissue samples, p. 389-427. In: R.L. Westerman (ed.). Soil testing and plant analysis. Soil Sci. Soc. Amer., Madison, WI.

Leavitt, M.J., C.C. Sheaffer, D.L. Wyse, and D.L. Allan. 2011. Rolled winter rye and hairy vetch cover crops lower weed density but reduce vegetable yields in no-tillage organic production. HortScience 46:387-395.

Licht, M.A. and M. Al-Kaisi. 2005. Strip-tillage effect on seedbed soil temperature and other soil physical properties. Soil Tillage Res. 80:233-249.

Lounsbury, N.P. and R.R. Weil. 2015. No-till seeded spinach after winterkilled cover crops in an organic production system. Renewable Agr. Food Systems 30:473-485.

Luna, J.M. and L. Staben. 2002. Strip tillage for sweet corn production: Yield and economic return. HortScience 37:1040-1044.

Mirsky, S.B., M.R. Ryan, J.R. Teasdale, W.S. Curran, C.S. Reberg-Horton, J.T. Spargo,
M.S. Wells, C.L. Keene, and J.W. Moyer. 2013. Overcoming weed management challenges in cover crop-based organic rotational no-till soybean production in the eastern United States. Weed Technol. 27:193-203.

Mochizuki, M.J., A. Rangarajan, R.R. Bellinder, H.M. van Es, and T. Björkman. 2008. Rye mulch management affects short-term indicators of soil quality in the transition to conservation tillage for cabbage. HortScience 43:862-867.

Nair, A., J. Tillman, and T. Coolong. 2015. Conservation techniques for vegetable production: Combining strip tillage and cover crops. Iowa State Ext. Outreach HORT3030.

Nyborg, M. and S.S. Malhi. 1989. Effect of zero and conventional tillage on barley yield and nitrate nitrogen content, moisture and temperature of soil in north-central Alberta. Soil Tillage Res. 15:1-9.

Peachey, R.E., R.D. William, and C. MallorySmith. 2004. Effect of no-till or conventional planting and cover crops residues on weed emergence in vegetable row crop. Weed Technol. 18:1023-1030.

Pieper, J.R., J.A. Amador, and R.N. Brown. 2015. Effects of three conservation tillage strategies on yields and soil health in a mixed vegetable production system. HortScience 50:1770 1776.

Plastina, A., E. Edwards, and A.M. Johanns. 2015. Cash rental rates for Iowa 2015 survey. 11 Jan. 2016. <https://www.extension.iastate. edu/agdm/wholefarm $/ \mathrm{html} / \mathrm{c} 2-10 . \mathrm{html}>$.

Ryan, M.R., W.S. Curran, A.M. Grantham, L.K. Hunsberger, S.B. Mirsky, D.A. Mortensen, E.A. Nord, and D.O. Wilson. 2011. Effects of seeding rate and poultry litter on weed suppression from a rolled cereal rye cover crop. Weed Sci. 59:438-444.

Schellenberg, D.L., R.D. Morse, and G.E. Welbaum. 2009. Organic broccoli production on transition soils: Comparing cover crops, tillage and sidedress N. Renew. Agr. Food Syst. 24:85-91.

Schillinger, W.F., A.C. Kennedy, and D.L. Young. 2007. Eight years of annual no-till cropping in Washington's winter wheat-summer fallow region. Agr. Ecosyst. Environ. 120:345-358.

Teasdale, J.R. and C.L. Mohler. 2000. The quantitative relationship between weed emergence and the physical properties of mulches. Weed Sci. 48:385-392.

U.S. Department of Agriculture (USDA). 2006. United States standards for grades of Italian sprouting broccoli. Agr. Mktg. Serv., Washington, DC.

U.S. Department of Agriculture-Agricultural Marketing Service (USDA-AMS). 2015. National Fruit and Vegetable Organic Summary. Agr. Mktg. Serv., Washington, DC.

Vollmer, E.R., N. Creamer, C. Reberg-Horton, and G. Hoyt. 2010. Evaluating cover crop mulches for no-till organic production of onions. HortScience 45:61-70.

Wells, M.S., S.C. Reberg-Horton, A.N. Smith, and J.M. Grossman. 2013. The reduction of plant-available nitrogen by cover crop mulches and subsequent effects on soybean performance and weed interference. Agron. J. 105:539-545.

Wood, C.W., D.W. Reeves, R.R. Duffield, and K.L. Edmisten. 1992. Field chlorophyll measurements for evaluation of corn nitrogen status. J. Plant Nutr. 15:487-500. 